\title{
EFEKTIVITAS PENGGUNAAN QUIZIZZ DALAM PEMBELAJARAN AKUNTANSI KONSOLIDASI BANK SYARIAH DI IAIN PONOROGO
}

\author{
Muhtadim Amri' ${ }^{1}$ Yuz Arija Shobri ${ }^{2}$ \\ ${ }^{1}$ Program Studi Perbankan Syariah, Institut Agama Islam Negeri Ponorogo, Indonesia \\ 2Program Studi Pendidikan Bahasa Arab, Institut Islam Negeri Maulana Malik Ibrahim, Indonesia \\ 1Jl. Pramuka No.156 Ponorogo \\ 2Jalan raya Ir. Soekarno No.1, Kota Batu \\ *Corresponding Author: muhtadinamri@iainponorogo.ac.id
}

\begin{abstract}
ABSTRAK
Penelitian ini bertujuan untuk mengetahui persepsi mahasiswa terhadap efektivitas penggunaan aplikasi pembelajaran berbasis permainan (game based learning) yaitu Quizizz. Populasi penelitian adalah seluruh mahasiswa perbankan syariah semester 4 angkatan tahun 2018. Responden dalam penelitian ini berjumlah 200 mahasiswa yang sedang menempuh mata kuliah akuntansi konsolidasi bank syariah yaitu mahasiswa semester 4 jurusan perbankan syariah di fakultas ekonomi dan bisnis islam IAIN Ponorogo. Analisis data dilakukan menggunakan metode deskriptif yang dianalisis secara kuantitatif dan kualitatif. Data penelitian diperoleh dengan menyebarkan survey kepada seluruh sampel penelitian dengan memanfaatkan aplikasi google forms. Instrumen kuesioner diukur menggunakan 5 skala likert yaitu sangat tidak setuju, tidak setuju, kurang setuju, setuju dan sangat tidak setuju. Hasil penelitian menunjukkan bahwa secara umum mahasiswa menganggap penggunaan Quizizz untuk mengerjakan kuis yang ditugaskan sebelum perkuliahan secara tatap muka di kelas berdampak yang positif dalam kegiatan pembelajaran pada mata kuliah akuntansi konsolidasi bank syariah. Mahasiswa menganggap Quizizz merupakan aplikasi yang mudah digunakan, penggunaannya membuat perkuliahan menjadi lebih menyenangkan, meningkatkan penguasaan materi, dan menambah motivasi dan keaktifan mahasiswa dalam mempelajari mata kuliah akuntansi konsolidasi bank syariah. Terdapat beberapa keterbatasan dan permasalahan yang terdapat pada penggunaan Quizizz menurut mahasiswa, diantaranya adalah keterbatasan koneksi internet, batasan waktu yang diberikan terlalu sedikit, dan beberapa mahasiswa juga merasa perlu untuk dilakukan pembahasan tentang soal-soal yang dikerjakan melalui aplikasi Quizizz di kelas, sehingga diketahui jawaban mana yang benar dan jawaban mana yang salah.
\end{abstract}

Kata kunci: Quizizz, Kuis, Akuntansi, Konsolidasi, Bank, Syariah.

\begin{abstract}
This research aims to determine student perceptions of the effectiveness of the use of Quizizz as a game based learning applications. The population of the research is all 4th semester sharia banking students class of 2018. Respondents in this research is sharia Banking students who take sharia banking consolidation accounting course for the academic year 2019/2020. Total respondents in this research is 210 with total returned and could be analyzed questionnaires is 169. Data analysis performed using descriptive method which analyzed using quantitative and qualitative analysis. The research data was obtained by distributing surveys to all research samples using Google Forms application. The questionnaire instrument was measured using five likert scale, that is strongly disagree, disagree, not agree, agree and strongly agree.The results showed that in general students considered the use of Quizizz to have a positive impact in learning activities on the sharia banking consolidation accounting course. Students' consider Quizizz is easy-to use application, makes lectures more fun, increase mastery of the material, and increase students' motivation and activeness in studying sharia banking consolidation accounting course. There are some limitations and problems found in using Quizizz according to students', including internet connection limitations, the time limit given is too little, and some students also feel the need to discuss about the questions that are done through the Quizizz application in class so that answers are known which is correct and which is wrong.
\end{abstract}


Keywords: Quizizz, Quiz, Accounting, Consolidation, Banking, Sharia

\section{PENDAHULUAN}

Penggunaan teknologi informasi dan komunikasi saat ini hampir sudah semakin tidak dapat dipisahkan dari kehidupan manusia. Lebih khusus lagi dengan meluasnya penggunaan perangkat telefon pintar (smartphone) yang saat ini sudah menjangkau hampir seluruh lapisan masyarakat, mulai dari usia dewasa hingga anakanak. Smartphone dianggap telah memberikan banyak bantuan dalam kehidupan manusia. Semakin meluasnya penggunaan smartphone tersebut merupakan faktor utama dari pengguna internet yang saat ini semakin meningkat.

Mayoritas penduduk Indonesia sudah menjadi pengguna internet. Asosiasi Penyelenggara Jasa Internet Indonesia (APJII) merilis data tentang jumlah pengguna internet di tahun 2018 telah mencapai angka 171,17 juta jiwa atau $64,8 \%$ dari total penduduk. Pertumbuhan pengguna internet di tahun 2018 bahkan telah mencapai angka 10,12\%. Jumlah tersebut lebih tinggi daripada pertumbuhan jumlah penduduk yang hanya $0,63 \%$ [1].

Perkembangan teknologi informasi dan komunikasi juga ikut memberikan dampak terhadap dunia pendidikan khususnya di bidang pembelajaran pengajaran. Dampak dari perkembangan tersebut diantaranya adalah terjadinya perubahan proses dan metode belajar siswa [2]. Sehingga, dibutuhkan para akademisi yang juga siap untuk mengadopsi teknologi informasi di dalam melaksanakan salah satu tugas dalam tridarma perguruan tinggi khususnya di bidang pengajaran [3]. Di sisi lain, bagi siswa sendiri berbagai kemudahan juga akan didapatkan dengan penggunaan teknologi informasi dalam pembelajaran tersebut [4]. Selain itu metode pembelajaran juga akan semakin mudah untuk dikembangkan menjadi semakin fleksibel dan efisien [5][10].

Dalam rangka memenuhi kebutuhan dunia pendidikan di era milenial saat ini, dibutuhkan integrasi antara teknologi informasi dan komunikasi dengan dunia pendidikan. Salah satu metode yang dapat ditempuh adalah dengan menggunakan media pembelajaran berbasis aplikasi online[6] dan atau dengan penggunaan metode pembelajaran berbasis permainan (gamebased learning). Materi yang diberikan oleh pengajar, akan lebih mudah dipahami oleh siswa dengan bantuan media pembelajaran yang tepat[2]. Metode dan media pembelajaran tersebut akhirakhir ini sedang populer digunakan. Hal tersebut didukung oleh munculnya aplikasi-aplikasi pendidikan berbasis permainan yang dilakukan secara online seperti Kahoot!, Socrative, iClickers, Edpuzzle, dan Quizizz yang sudah banyak digunakan oleh berbagai pihak [7] Pendekatan pembelajaran dengan menggunakan permainan ini dapat memberikan pengalaman belajar yang baru bagi siswa [8]

Siswa menjadi lebih aktif, suasana pembelajaran yang lebih dinamis dan tambahan pengalaman belajar secara umum adalah beberapa manfaat yang dapat diperoleh dari penggunaan aplikasi-aplikasi berbasis permainan [9]. Hal ini juga didukung oleh literatur pada penelitian terdahulu yang menyatakan bahwa penggunaan media pembelajaran berbasis teknologi secara umum dianggap lebih baik daripada sistem tradisional.[10] Meskipun demikian, penggunaan teknologi informasi dalam dunia pendidikan di kalangan para akademisi baik di tingkat sekolah dasar, menengah, hingga universitas tersebut sekarang sudah menjadi sebuah tren. Para akademisi di bidang akuntansi masih jarang yang bersedia untuk menggunakan inovasi pembelajaran berbasis teknologi informasi dan lebih memilih untuk menggunakan metode-metode tradisional [11].

Umumnya, mahasiswa menganggap mata kuliah akuntansi sebagai mata kuliah yang penuh dengan angka-angka yang rumit,sehingga dianggap sebagai mata kuliah yang sulit dan membosankan. Permasalahan lain dalam pembelajaran akuntansi 
adalah banyak mahasiswa yang belajar di fakultas ekonomi dan bisnis mengalami kegagalan pada mata kuliah ini. Kondisi tersebut seharusnya mendorong para akademisi khususnya dosen akuntansi untuk melakukan inovasi dan variasi dalam kegiatan pembelajaran. Sehingga diharapkan persepsi mahasiswa terhadap mata kuliah akuntansi yang selama ini masih kurang baik bisa berubah. Diantara Inovasi dan variasi metode pembelajaran akuntansi yang menarik dan menyenangkan adalah dengan menggunakan aplikasi pengerjaan soal-soal dalam bentuk permainan [12].

Quizizz merupakan satu diantara banyak aplikasi yang dapat dimanfaat sebagai penunjang kegiatan pembelajaran. Aplikasi ini dapat digunakan oleh seluruh pengguna untuk bermain dan mengerjakan kuis di kelas ataupun di luar kelas secara gratis. Dengan menggunakan Quizizz, mahasiswa dapat mengerjakan kuis sesuai dengan pilihan waktu pengerjaan sesuai dengan yang mereka inginkan. Beberapa kelebihan yang dimiliki oleh Quizizz dibandingkan aplikasi yang lain diantaranya adalah adanya papan peringkat (leaderboard) yang memungkinkan bagi peserta kuis untuk mengetahui nilai dan peringkat peserta kuis dibandingkan dengan peserta lain [13] .

Beberapa penelitian sebelumnya telah melakukan penyelidikan tentang variasi penggunaan Quizizz dengan cara dan metode yang berbeda-beda. Penelitian-penelitian tersebut telah membuktikan adanya manfaat dari penggunaan aplikasi Quizizz dalam kegiatan belajar mengajar. Penggunaan Quizizz dalam pembelajaran di kelas akuntansi memberikan pengaruh yang positif terhadap mahasiswa [13]. Penelitian tersebut menjelaskan bahwa mahasiswa lebih senang jika Quizizz digunakan selama pembelajaran di kelas secara berkala. Menggunakan Quizizz dalam mata kuliah Kimia Fisika 1 mampu meningkatkan konsentrasi [14]. Aplikasi Quizizz memberikan dampak yang lebih baik pada kelas yang menggunakan secara berkala dibandingkan dengan kelas yang hanya sekali menggunakan Quizizz[13], meningkatkan hasil belajar dan keterampilan siswa pada bidang matematika di tingkat Sekolah Menengah Atas (SMA) [12] meningkatkan kemampuan penguasaan grammar [15].

Dari penjelasan tersebut dapat kita ketahui bahwa penggunaan Quizizz sebagai media pembelajaran, telah menarik minat dari para akademisi untuk melakukan penelitian yang bertujuan menginvestigasi efektivitas dari penggunaan Quizizz sebagai media pembelajaran pada berbagai metode dan konteks yang berbeda. Meskipun sudah terdapat penelitian terdahulu yang melakukan penelitian tentang efektivitas Quizizz dalam pembelajaran, sejauh pengetahuan peneliti, masih jarang penelitian yang menganalisis efektifitas penggunaan Quizizz sebagai metode pembelajaran dan bagaimana persepsi mahasiswa khususnya mahasiswa Perguruan Tinggi Keagamaan Islam Negeri (PTKIN) terlebih khusus lagi di kelas mata kuliah akuntansi. Hal ini dikarenakan mata kuliah akuntansi pada umumnya dianggap oleh mahasiswa sebagai mata kuliah yang rumit dan membosankan [15]. Alasan penting lain melakukan penelitian dari efektivitas penggunaan Quizizz pada konteks PTKIN adalah karena masih jarang para akademisi khususnya di PTKIN yang menggunakan aplikasi pembelajaran seperti Quizizz ini dalam kegiatan pembelajaran . Sehingga, hal tersebut mendorong peneliti untuk melakukan penelitian lebih lanjut tentang efektivitas penggunaan Quizizz dalam konteks PTKIN khususnya pada mata kuliah akuntansi yang dalam penelitian ini diterapkan pada mata kuliah akuntansi konsolidasi bank syariah.

Tujuan dari penelitian ini adalah untuk mengetahui persepsi mahasiswa tentang efektivitas penggunaan Quizizz pada mata kuliah akuntansi. Mata kuliah akuntansi yang dipilih dalam penelitian ini adalah mata kuliah akuntansi konsolidasi bank syariah. Dalam mata kuliah akuntansi konsolidasi bank syariah, mahasiswa diberikan tugas untuk mengerjakan kuis d rumah sebelum mempelajari materi secara tatap muka di kelas. Dengan diberikannya kuis terlebih dahulu, diharapkan mahasiswa akan mempelajari materi di rumah, sebelum berdiskusi tentang materi di kelas. Responden penelitian adalah mahasiswa yang sedang mengikuti mata kuliah akuntansi konsolidasi bank syariah. Aspek yang diuji dalam penelitian ini adalah tentang apakah Quizizz adalah aplikasi yang menyenangkan dan manfaat apa saja yang didapatkan oleh mahasiswa, dari penggunaan Quizizz dalam mata kuliah akuntansi konsolidasi bank syariah dilihat dari tingkat pemahaman tentang materi, keaktifan belajar, motivasi dan ketertarikan untuk mempelajari materi yang harus dikuasai. 


\section{METODE}

Penelitian ini menggunakan metode campuran (mix method) yaitu metode kuantitatif dan kualitatif. Jenis data dalam penelitian ini adalah data primer. Pengumpulan data kuantitatif dilakukan dengan menyebarkan kuesioner berupa angket dengan pernyataan tertutup. Sedangkan data kualitatif dikumpulkan dengan menyebarkan angket dengan pertanyaan terbuka. Kuesioner dibagikan kepada seluruh mahasiswa perbankan syariah angkatan 2018 melalui grup WhatsApp di masing-masing grup kelas yang berjumlah 7 kelas. Kuesioner disusun menggunakan alat bantu google forms. Total mahasiswa aktif jurusan perbankan syariah IAIN Ponorogo angkatan 2018 yang mengikuti mata kuliah akuntansi konsolidasi bank syariah di semester 4 tahun akademik 2019/2020 ini adalah 214 mahasiswa. Sementara, total angket yang kembali dan dapat dianalisis berjumlah 169 .

Instrumen kuesioner kuantitatif dalam penelitian ini terdiri dari 16 pernyataan yang diukur menggunakan skala likert. Pernyataan positif diukur dengan sangat tidak setuju memiliki skor 1 , tidak setuju memiliki skor 2, kurang setuju memiliki skor 3 , setuju memiliki skor 4 dan sangat setuju memiliki skor 5. Sedangkan pernyataan negatif diukur dengan skor 5 sangat tidak setuju, skor 4 tidak setuju, skor 3 kurang setuju, skor 2 setuju, dan skor 1 sangat setuju.

Selain instrumen menggunakan pernyataan tertutup, instrumen penelitian juga menyertakan pertanyaan terbuka. Hal tersebut bertujuan untuk mengetahui secara lebih mendalam tentang persepsi mahasiswa tentang efektivitas penggunaan aplikasi Quizizz. Pada instrumen pertanyaan terbuka ditanyakan tentang bagaimana komentar mahasiswa tentang aplikasi Quizizz. Pertanyaan tersebut kemudian dianalisis secara kualitatif.

Instrumen penelitian penelitian ini mengacu pada instrumen penelitian yang digunakan dalam penelitian yang telah dibuat sebelumnya [13]. Hasil dari kuesioner kemudian dianalisis secara statistik deskriptif dengan melihat nilai rata-rata (mean) dari masing-masing indikator untuk menentukan bagaimana persepsi mahasiswa terhadap efektivitas penggunaan Quizizz dalam mata kuliah akuntansi konsolidasi bank syariah terkait dengan aspek kemudahan, penguasaan materi, kepuasan, motivasi dan keaktifan. Hasil dari skor rata-rata tersebut kemudian dicocokkan dengan klasifikasi persepsi responden sesuai dengan tabel 1 berikut ini [17]:

Tabel 1. Klasifikasi Persepsi Responden

\begin{tabular}{cc}
\multicolumn{2}{c}{ Tabel 1. Klasifikasi Persepsi Responden } \\
\hline Rata-rata Skor Jawaban & Klasifikasi Sikap \\
\hline$>3,4 \mathrm{~s} / \mathrm{d} 5,0$ & Sangat Setuju \\
$>2,6 \mathrm{~s} / \mathrm{d} 3,4$ & Setuju \\
$>1,8 \mathrm{~s} / \mathrm{d} 2,6$ & Kurang Setuju \\
$1,0 \mathrm{~s} / \mathrm{d} 1,8$ & Tidak Setuju \\
\hline
\end{tabular}

\section{HASIL DAN PEMBAHASAN}

Data yang diperoleh dari hasil survey kuesioner yang dibagikan kepada mahasiswa perbankan syariah semester 4 angkatan 2018 yang sedang menempuh mata kuliah akuntansi konsolidasi bank syariah dapat dilihat pada tabel $2 \mathrm{~s} / \mathrm{d}$ tabel 12 .

Tabel 2. Indikator Kemudahan

\begin{tabular}{lcl}
\hline \multicolumn{1}{c}{ Pernyataan } & Mean & Std. dev \\
\hline $\begin{array}{l}\text { Quizizz mudah digunakan. } \\
\text { Saya lebih mudah mengerjakan kuis dengan }\end{array}$ & 4,05 & 0,78 \\
$\begin{array}{l}\text { aplikasi Quizizz di smartphone daripada kuis } \\
\text { menggunakan kertas. }\end{array}$ & $4,020,90$ \\
\hline
\end{tabular}

Indikator kemudahan dapat dilihat pada tabel 2. Berdasarkan tabel 2 nilai rata-rata (mean) dari pertanyaan yang diberikan kepada mahasiswa adalah 4,05. Hal ini menunjukkan bahwa jawaban mahasiswa termasuk dalam kategori setuju karena nilainya berada pada skor $>3,4$ s/d 4,2. Dapat disimpulkan bahwa mahasiswa menganggap aplikasi Quizizz merupakan aplikasi yang mudah digunakan. Untuk pernyataan tentang pilihan antara kuis menggunakan kertas (paper based test) atau menggunakan aplikasi juga menunjukkan nilai rata-rata 4,02. Hasil tersebut mengindikasikan bahwa dalam pembelajaran akuntansi konsolidasi bank syariah mahasiswa menilai penggunaan aplikasi Quizizz untuk mengerjakan kuis dianggap lebih mudah dibandingkan dengan kuis menggunakan kertas.

Hasil dari pernyataan tertutup tersebut juga diperkuat oleh beberapa jawaban mahasiswa atas pertanyaan terbuka yang dapat dilihat pada tabel 3 berikut ini: 
Tabel 3. Jawaban pertanyaan terbuka terkait kemudahan penggunaan

Sangat mudah dalam membantu proses belajar , bisa dilihat dimana aja dan bisa dikerjakan dimanapun tempatnya tidak hanya di kelas.

Tidak ribet.

Lebih praktis daripada mengerjakan soal di kertas. Tapi sering lupa tidak mengerjakan.

Pengalaman saya saat menggunakan aplikasi tersebut mudah dan tidak terlalu rumit dalam mengerjakannya.

Lebih mudah, karena tidak perlu menulis secara manual

Indikator berikutnya adalah tentang bagaimana persepsi mahasiswa terhadap efektivitas penggunaan Quizizz dalam membantu penguasaan materi. Hasil dari kuesioner yang disebarkan kepada mahasiswa yang menunjukkan indikator efektivitas penggunaan Quizizz dalam membantu mahasiswa untuk meguasai materi dalam mata kuliah akuntansi konsolidasi bank syariah dapat dilihat pada tabel 4.

Tabel 4. Indikator Penguasaan Materi

\begin{tabular}{lcc}
\hline \multicolumn{1}{c}{ Pernyataan } & Mean & Std. dev \\
\hline $\begin{array}{l}\text { Quizizz membantu saya mengingat kembali } \\
\text { materi yang telah dipelajari di kelas. }\end{array}$ & 3,82 & 0,74 \\
$\begin{array}{l}\text { Quizizz membantu saya mengetahui materi } \\
\text { apa yang belum saya kuasai. }\end{array}$ & 3,83 & 0,79 \\
$\begin{array}{l}\text { Quizizz meningkatkan pemahaman saya } \\
\text { tentang akuntansi konsolidasi bank syariah. }\end{array}$ & 3,7 & 0,76 \\
\hline
\end{tabular}

Berdasarkan tabel 4 diketahui bahwa mahasiswa setuju dengan pernyataan bahwa penggunaan Quizizz dapat membantu dalam penguasaan materi pada mata kuliah akuntansi konsolidasi bank syariah. Hal tersebut ditunjukkan dengan nilai rata-rata dari pernyataan-pernyataan yang menjadi indikator bahwa Quizizz meningkatkan penguasaan materi pada mata kuliah akuntansi konsolidasi bank syariah menunjukkan nilai 3,82, 3,83 dan 3,70. Hal ini menunjukkan bahwa jawaban mahasiswa termasuk dalam kategori setuju karena nilai ratarata dari jawaban mahasiswa yang menjadi responden adalah antara $>3,4 \mathrm{~s} / \mathrm{d} \mathrm{4,2}$. Dari hasil tersebut dapat disimpulkan bahwa penggunaan Quizizz dapat membantu mahasiswa untuk mengingat materi yang telah dipelajari di kelas, mengetahui materi apa yang belum dikuasai dan meningkatkan pemahaman pada materi-materi yang dipelajari pada mata kuliah akuntansi konsolidasi bank syariah.

Hasil dari pernyataan tertutup yang menyatakan bahwa mahasiswa setuju jika penggunaan aplikasi Quizizz membantu dalam penguasaan materi tersebut juga diperkuat oleh beberapa jawaban mahasiswa atas pertanyaan terbuka yang dapat dilihat pada tabel 5 berikut ini:

Tabel 5. Jawaban pertanyaan terbuka terkait penguasaan materi

Menurut saya quizizz lumayan saya sukai, karena saya bisa mengingat materi yg sudah dipresentasikan di dalam kelas

Menggunakan apps Quizzz menambah pengetahuan tentang akuntansi konsolidasi bank syariah yang belum saya pahami ketika dijelaskan dikelas dan dapat memotivasi untuk mendapatkan poin dan peringkat yang baik dan bisa lebih suka belajar akuntansi konsolidasi

Penggunaan aplikasi quizizz memudahkan mahasiswa untuk mengulas kembali materi yang telah di berikan sebelumnya, jadi menurut saya aplikasi quizizz ini berguna untuk menguji kemampuan daya serap mahasiswa setelah menerima materi yang diberikan lewat youtube. Dan semoga cara ini dapat dilanjutkan kedepannya

Aplikasi yg membantu untuk lebih memahami materi mata kuliah sebelum kelas dimulai

Quizizz memudahkan saya untuk mempelajari banyak hal tentang akuntansi konsolidasi

Indikator berikutnya adalah tentang bagaimana kepuasan mahasiswa terhadap penggunaan Quizizz dalam membantu membuat perkuliahan akuntansi konsolidasi bank syariah menjadi lebih menyenangkan.

Tabel 6. Indikator Kepuasan

\begin{tabular}{lcc}
\hline \multicolumn{1}{c}{ Pernyataan } & Mean & Std. dev \\
\hline $\begin{array}{l}\text { Quizizz menurut saya adalah aplikasi yang } \\
\text { menyenangkan. }\end{array}$ & 3,91 & 0,82 \\
$\begin{array}{l}\text { Quizizz membuat belajar akuntansi } \\
\text { konsolidasi bank syariah menjadi lebih } \\
\text { menyenangkan. }\end{array}$ & 3,82 & 0,70 \\
$\begin{array}{l}\text { Quizizz mengurangi rasa takut saya pada } \\
\text { mata kuliah akuntansi konsolidasi bank } \\
\text { syariah. }\end{array}$ & 3,57 & 0,87 \\
$\begin{array}{l}\text { Quizizz membuat kuis menjadi } \\
\text { membosankan. }\end{array}$ & 3,50 & 0,87 \\
\hline
\end{tabular}

Berdasarkan tabel 6 nilai rata-rata dari pertanyaan yang diberikan kepada mahasiswa untuk setiap pernyataan adalah antara $3,5 \mathrm{~s} / \mathrm{d}$ 3,91. Hal ini menunjukkan bahwa jawaban mahasiswa masuk dalam kategori setuju karena nilainya berada pada skor $>3,4 \mathrm{~s} / \mathrm{d} 4,2$. Kesimpulan dari hasil tersebut adalah mahasiswa merasa puas dengan aplikasi Quizizz. Dari pernyataanpernyataan yang diberikan juga mengindikasikan bahwa penggunaan Quizizz pada matakuliah akuntansi konsolidasi bank syariah dapat membuat suasana belajar menjadi lebih menyenangkan dan mengurangi rasa takut mahasiswa terhadap perkuliahan khususnya akuntansi konsolidasi bank syariah. Hasil ini juga diperkuat dengan skor pernyataan negatif yaitu 
Quizizz membuat kuis menjadi membosankan yang memiliki skor 3,50. Hasil tersebut mengindikasikan mahasiswa cenderung tidak setuju jika penggunaan Quizizz membuat kuis menjadi membosankan.

Hasil dari pernyataan tertutup tersebut juga diperkuat oleh beberapa jawaban mahasiswa atas pertanyaan terbuka yang menunjukkan berdasarkan persepsi mahasiswa, aplikasi Quizizz adalah aplikasi yang menyenangkan. Hal tersebut dapat dilihat dari beberapa komentar mahasiswa pada tabel berikut ini:

Tabel 7. Jawaban pertanyaan terbuka terkait penguasaan materi Pembelajaran di kelas jadi lebih keren

Quizizz sangat mudah digunakan,Dan apl yang tidak membosankan,membuat belajar lebih senang dan mudah dipahami

Menurut saya dalam menggunakan quizizz dalam pembelajaran untuk nengerjaan soal sangat menyenangkan dan tidak membosankan sebab pas waktu memgerjakan ada batas waktunya sehingga membuat itu sangat seru dan di dalam aplikasi quizizz kita mengetahui rangking atau peringkat setelah kita mengerjakan soal jadi menambah saya untuk giat belajar untuk mendapatkan rangking pertama

Quizizz membuat saya tidak bosan belajar akuntansi konsoldasi bank syariah, karena tidak monoton presentasi, tetapi ada persaingan antar teman belajar

Menyenangkan, jika waktu hampir habis bikin heboh sendiri akirnya sering jawabnya pakai logika

Menyenangkan sekaligus deg-degan

Quizizz sangat menyenangkan, tidak membosankan. Belajar sambil mengumpulkan poin. Kadang juga ada pembahasan soal yang salah. Jadi bisa mereview materi yang belum paham. Saran, kalau bisa setiap selesai kuis selalu ada pembahasan agar belajar jadi lebih mudah

Mengasyikkan

Indikator selanjutnya adalah tentang bagaimana persepsi mahasiswa terhadap efektivitas penggunaan Quizizz dalam meningkatkan motivasi belajar di mata kuliah akuntansi konsolidasi bank syariah.

Tabel 8. Indikator Motivasi

\begin{tabular}{lcc}
\hline \multicolumn{1}{c}{ Pernyataan } & Mean & Std. dev \\
\hline $\begin{array}{l}\text { Quizizz meningkatkan ketertarikan saya } \\
\text { untuk mempelajari akuntansi konsolidasi } \\
\text { bank syariah. }\end{array}$ & 3,67 & 0,69 \\
$\begin{array}{l}\text { Motivasi belajar saya pada mata kuliah } \\
\text { akuntansi konsolidasi bank syariah }\end{array}$ & & \\
$\begin{array}{l}\text { meningkat karena terdapat tampilan } \\
\text { peringkat (leaderboard) skor dari peserta } \\
\text { lain. }\end{array}$ & 3,82 & 0,80 \\
$\begin{array}{l}\text { Saya termotivasi untuk memperoleh } \\
\text { peringkat dan skor tertinggi ketika } \\
\text { menggunakan Quizizz. }\end{array}$ & 4,12 & 0,70
\end{tabular}

Quizizz meningkatkan rasa keingintahuan saya terhadap mater-materi yang dipelajari dalam mata kuliah akuntansi konsolidasi 3,85 0,64 bank syariah.

Berdasarkan tabel 8 Motivasi, nilai rata-rata dari pernyataan yang diberikan kepada mahasiswa adalah 3,67 s/d 4,12. Hal ini menunjukkan bahwa jawaban dari mahasiswa termasuk ke dalam kategori setuju bahwa penggunaan Quizizz meningkatkan motivasi mahasiswa karena nilainya berada pada rentan $>3,4 \mathrm{~s} / \mathrm{d}$ 4,2. Hasil ini menunjukkan bahwa penggunaan aplikasi Quizizz dalam pembelajaran mata kuliah akuntansi konsolidasi dapat meningkatkan motivasi belajar mahasiswa. Mahasiswa setuju bahwa aplikasi tersebut meningkatkan ketertarikan motivasi belajar, dan rasa keingintahuan terhadap materimateri yang dipelajari dalam mata kuliah akuntansi konsolidasi bank syariah. Dari empat pernyataan yang ada di tabel 5, dapat dilihat skor rata-rata terbesar yaitu 4,12 adalah skor pada pernyataan yang menunjukkan mahasiswa termotivasi untuk memperoleh skor tertinggi ketika menggunakan Quizizz. Hal ini mengindikasikan mahasiswa memiliki ketertarikan yang tinggi untuk saling berkompetisi untuk mendapatkan skor dan peringkat tertinggi dibandingkan dengan peserta lainnya dalam kuis yang diberikan menggunakan aplikasi Quizizz.

Hasil dari pernyataan tertutup tersebut juga diperkuat oleh beberapa jawaban mahasiswa atas pertanyaan terbuka yang menunjukkan bahwa penggunaan aplikasi Quizizz dapat meningkatkan motivasi belajar. Hal tersebut dapat dilihat dari beberapa komentar mahasiswa pada tabel berikut ini:

Tabel 9. Jawaban pertanyaan terbuka terkait motivasi

Sangat menyenangkan dan menambah motivasi untuk belajar Melalui aplikasi ini meningkatkan motivasi belajar dari diri saya karena aplikasinya menyenangkan

Termotivasi untuk mempelajari materi sebelum mengerjakan, karena merasa kurang PD jika skor dipublikasi dan mendapat skor rendah. Mempermudah mengingat materi jika suatu saat review

Menurut saya quiz ini membuat saya termotivasi untuk belajar apalagi saat melihat skor setelah di tampilkan usai mengerjakan Dengan quizzz belajar lebih meningkat dan semakin semangaaatttt

Dengan adanya aplikasi quizzz mempermudah saya untuk mengingat meteri yang telah di ajarkan, dan kuisnya seru selain itu juga bisa mengetahui berapa skornya sehingga bisa memotivasi diri untuk belajar jika skornya kurang memuaskan 


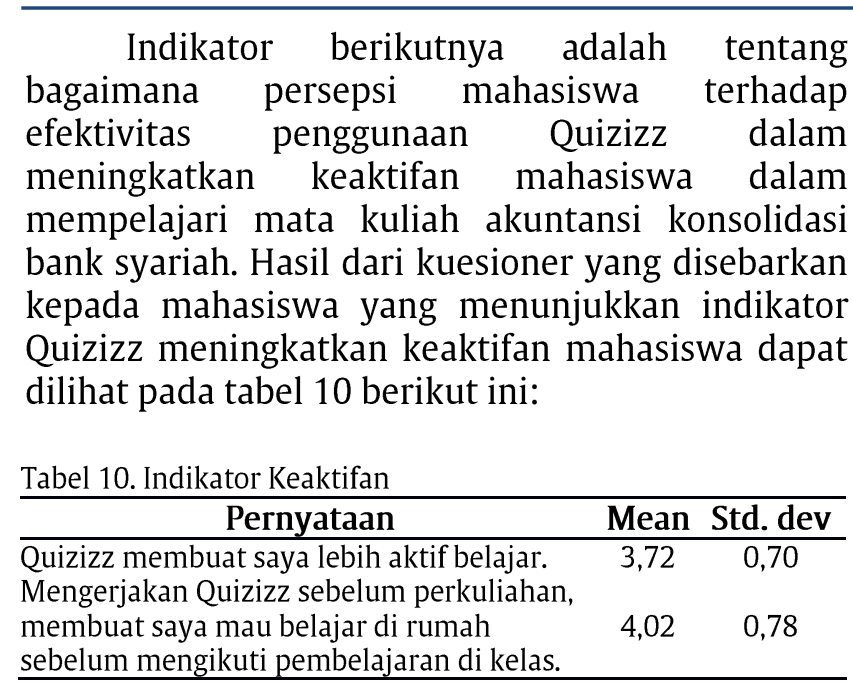

Berdasarkan tabel 10, nilai rata-rata dari masing-masing pernyataan yang diberikan kepada mahasiswa adalah antara 3,72 s/d 4,02. Jika dilihat dari klasifikasi persepsi responden di tabel 1 jawaban mahasiswa termasuk dalam kategori setuju karena nilainya berada pada rentan $>3,4 \mathrm{~s} / \mathrm{d}$ 4,2. Hasil ini mengindikasikan bahwa aplikasi Quizizz membuat mahasiswa lebih aktif belajar. Skor yang mendorong mahasiswa untuk mempelajari materi di rumah sebelum mengikuti pembelajaran akuntansi konsolidasi bank syariah di kelas adalah 4,02. Skor tersebut cukup tinggi sehingga hal ini menunjukkan pemberian Quizizz sebelum perkuliahan membuat mahasiswa bersedia untuk mempelajari materi terlebih dahulu sebelum mengikuti pembelajaran secara tatap muka di kelas.

Hasil dari pernyataan tertutup tersebut juga diperkuat oleh beberapa jawaban mahasiswa atas pertanyaan terbuka yang diajukan dalam kuesioner. Mahasiswa menganggap bahwa aplikasi Quizizz membuat mahasiswa lebih aktif belajar. Hal tersebut dapat dilihat dari beberapa komentar mahasiswa pada tabel 11 berikut ini:

\section{Tabel 11. Jawaban pertanyaan terbuka terkait keaktifan}

Menggunakan Quizizz Apps membantu saya lebih semangat
untuk belajar. Dengan tema yang menarik, membuat saya
tertarik dan mengerjakan quiz menjadi tidak membosankan
Pengalaman saya menggunakan aplikasi quizzz pada mata
kuliah akuntansi konsolidasi bank syariah adalah dalam
mengerjakan quizizz saya harus membuka buku. Sama halnya
saya selalu di ingatkan untuk selalu belajar mata kuliah ini.
Tampilan quizizz juga menarik bagi saya.
Sangaaaat membantu saya untuk mendobrak semangat belajar,
karena dengan quizizz bisa mengukur kemampuan kefahaman
belajar saya
Akan senantiasa belajar jika akan mengerjakan quiz
Quizizz membuat saya untuk belajar lebih dari biasanya, Quizizz
adalah aplikasi kuis yang cukup menyenangkan

Selain berbagai manfaat dari penggunaan Quizizz yang telah disebutkan seperti penggunaan aplikasi yang mudah, membantu penguasaan materi, membuat perkuliahan menjadi lebih menyenangkan, meningkatkan motivasi belajar, dan juga membuat mahasiswa lebih aktif belajar. Dari pertanyaan terbuka yang diberikan, mahasiswa juga memberikan tanggapan beberapa kekurangan dan kelemahan dari penggunaan Quizizz selama perkuliahan akuntansi konsolidasi bank syariah. Beberapa jawaban yang diberikan oleh mahasiswa terkait dengan kekurangan dari penggunaan aplikasi tersebut dapat dilihat di tabel 12 berikut ini:

\section{Tabel 12. Persepsi mahasiswa}

Mengerjakan kuis h min 2 menit karena ga punya kuota dan harus cari wifi terlebih dahulu.

Kalau sinyalnya tidak bagus lemot pak

Ribet karena terkadang sinyal.nya hilang atau log out sendiri karena ada batas waktu sehingga membuat saya tidak fokus untuk memahami soal

Kurangnya waktu dalam mengerjakan soal

Kurang memahami materi yang ada di Quizizz,lebih baik dibahas di dalam kelas agar lebih tau jawaban yang benar dengan didiskusikan bersama sama.Karena saya belum bisa memahami materinya sampai saat ini,waktu nya terlalu cepat dalam mengerjakannya.

Berdasarkan tabel 12, maka dapat diindikasikan terdapat beberapa keterbatasan dan permasalahan yang terdapat pada penggunaan Quizizz dalam pembelajaran di mata kuliah akuntansi konsolidasi bank syariah adalah keterbatasan koneksi internet, batasan waktu yang diberikan terlalu sedikit, dan beberapa mahasiswa juga merasa perlu untuk dilakukan pembahasan tentang soal-soal yang dikerjakan melalui aplikasi Quizizz di kelas, sehingga diketahui jawaban mana yang benar dan jawaban mana yang salah.

\section{KESIMPULAN}

Kesimpulan dari penelitian adalah ditemukan bukti bahwa secara umum penggunaan Quizizz memberikan dampak yang positif dalam pembelajaran mata kuliah akuntansi konsolidasi bank syariah. Mahasiswa menganggap Quizizz adalah aplikasi yang mudah digunakan. Selain itu, penggunaan Quizizz selama proses pembelajaran juga dapat meningkatkan pemahaman mahasiswa terkait materi yang sudah dan akan dipelajari di kelas. Mahasiswa juga merasa puas dengan penggunaan Quizizz selama perkuliahan dan 
merasa bahwa Quizizz merupakan aplikasi yang menyenangkan. Mahasiswa juga menjadi lebih tertarik dan merasa bahwa dengan Quizizz mata kuliah akuntansi yang biasanya membosankan menjadi lebih menyenangkan.

Quizizz juga dianggap juga terbukti meningkatkan motivasi belajar. Mahasiswa termotivasi untuk memperoleh skor tertinggi dan mendapatkan peringkat teratas di antara peserta kuis yang lain. Selain itu, pemberian tugas untuk mengerjakan kuis dengan Quizizz sebelum perkuliahan dilaksanakan juga meningkatkan rasa keingintahuan mahasiswa terkait materi yang akan dipelajari di kelas.

Quizizz juga terbukti membuat mahasiswa lebih aktif belajar. Mahasiswa terdorong untuk bersedia meluangkan waktu belajar di rumah sebelum mengikuti perkuliahan di kelas. Dari hasil temuan-temuan tersebut dapat disimpulkan bahwa mahasiswa merasakan manfaat dari penggunaan Quizizz selama mengikuti perkuliahan akuntansi konsolidasi bank syariah.

Secara keseluruhan, hasil dari penelitian ini semakin memperkuat kesimpulan penelitianpenelitian yang telah dilakukan sebelumnya yang menunjukkan bahwa siswa atau mahasiswa menilai penggunaan Quizizz memberikan dampak yang positif dalam kegiatan pembelajaran.

Terdapat beberapa keterbatasan dan permasalahan yang terdapat pada penggunaan Quizizz dalam pembelajaran di mata kuliah akuntansi konsolidasi bank syariah. Diantara bentuk keterbatasan yang dialami oleh mahasiswa adalah koneksi internet yang lemah, batasan waktu yang diberikan terlalu sedikit, dan beberapa mahasiswa juga merasa perlu untuk dilakukan pembahasan tentang soal-soal yang dikerjakan melalui aplikasi Quizizz di kelas, sehingga diketahui jawaban mana yang benar dan jawaban mana yang salah.

Implikasi dari penelitian ini diantaranya adalah selanjutnya para akademisi di bidang akuntansi khususnya di PTKIN agar lebih inovatif lagi dalam menggunakan media pembelajaran. Quizizz merupakan salah satu media yang dapat digunakan sebagai media untuk memberikan kuis menggantikan penggunaan kertas. Selain itu, para bagi para pendidik juga perlu memperhatikan beberapa keterbatasan atau kelemahan dari penerapan Quizizz yang ada dalam penelitian ini. Penelitian ini memiliki beberapa keterbatasan, pertama, subjek yang dijadikan populasi dalam penelitian ini hanyalah mahasiswa perbankan syariah angkatan 2018 yang sedang mengikuti mata kuliah akuntansi konsolidasi bank syariah, sehingga hasil penelitian hanya dapat menyimpulkan kondisi yang terjadi pada responden penelitian saja, kesimpulan yang dihasilkan dari penelitian mungkin tidak dapat diterapkan pada kondisi dan konteks di tempat lain yang berbeda. Kedua, analisis yang digunakan adalah analisis deskriptif menggunakan instrumen penelitian yang diukur menggunakan skala likert. Hal ini mengakibatkan analisis kesimpulan masih didasarkan pada persepsi saja yang dinilai dalam penelitian ini, sehingga belum terlalu mendalam menjelaskan bagaimana pengalaman sesungguhnya dari mahasiswa berdasarkan fenomena yang terjadi [9]. Sehingga perlu dilakukan penelitian dengan metode kualitatif dengan pengumpulan data menggunakan wawancara secara lebih mendalam kepada mahasiswa.

\section{SARAN}

Saran dari penelitian ini adalah, berdasarkan hasil penelitian maka para akademisi akuntansi khususnya di lingkungan PTKIN dapat menggunakan Quizizz sebagai salah satu alternatif media pembelajaran yang menyenangkan. Dibutuhkan penelitian lebih lanjut untuk memastikan hasil yang lebih akurat dari efektivitas penggunaan quizizz. Bagi penelitian selanjutnya juga diharapkan untuk melakukan penelitian dengan responden yang lebih beragam dan dapat juga menggunakan metode penelitian yang berbeda, sehingga dari hasil penelitian dengan konteks yang berbeda-beda tersebut, dapat dihasilkan kesimpulan tentang efektivitas dari penggunaan Quizizz yang lebih konklusif.

\section{DAFTAR PUSTAKA}

[1] Asosiasi Penyelenggara Jasa Internet Indonesia, "Laporan Survei Penetrasi \& Profil Perilaku Pengguna Internet di Indonesia 2018," 2018.

[2] W. J. A. Ramadhani, "Jurnal Teknologi Informasi dan Pendidikan," J. Teknol. Komun. dan Pendidik., vol. 12, no. 1, p. 4, 2019. 
[3] B. Centauri, "Efektivitas Kahoot! Sebagai Media Pembelajaran Kuis Interaktif Di SDN-7 Bukit Tunggal," no. September, pp. 124-133, 2019.

[4] G. Damara, "Students' Perceptions on the Use of Kahoot! As An Ice Breaker in Movie Interpretation Class," 2016.

[5] Y. Huda and D. Faiza, "Desain Sistem Pembelajaran Jarak Jauh Berbasis Smart Classsroom Menggunakan Layanan Live Video Webcasting," J. Teknol. Inf. dan Pendidik., 2019, doi: 10.24036/tip.v12i1.173.

[6] E. Ratnasari, R. Hikmawati, R. N. Ghifari, and U. Majalengka, "Quizizz Application As Gamification Platform To Bridge Students In Teaching," no. 2003, pp. 1333-1337, 2019.

[7] A. I. Wang, M. Zhu, and R. Sætre, "The effect of digitizing and gamifying quizzing in classrooms," Proc. Eur. Conf. Games-based Learn., vol. 2016-Janua, no. Sharples 2000, pp. 729-737, 2016.

[8] H. Bicen and S. Kocakoyun, "Perceptions of students for gamification approach: Kahoot as a case study," Int. J. Emerg. Technol. Learn., vol. 13, no. 2, pp. 72-93, 2018, doi: 10.3991/ijet.v13i02.7467.

[9] S. A. Licorish, H. E. Owen, B. Daniel, and J. L. George, "Students' perception of Kahoot!' s influence on teaching and learning," 2018.

[10] C. Fies and J. Marshall, "Classroom response systems: A review of the literature," J. Sci. Educ. Technol., vol. 15, no. 1, pp. 101-109, 2006, doi: 10.1007/s10956-006-0360-1.

[11] K. Watty, J. McKay, and L. Ngo, "Innovators or inhibitors? Accounting faculty resistance to new educational technologies in higher education," J. Account. Educ., vol. 36, pp. 1-15, 2016.

[12] A. Setiawan, S. Wigati, and D. Sulistyaningsih, "Implementasi Media Game Edukasi Quizizz Untuk Meningkatkan Hasil Belajar Matematika Materi Sistem Persamaan Linear Tiga Variabel Kelas X IPA 7 SMA Negeri 15 Semarang Tahun Pelajaran 2019 / 2020," pp. 167-173, 2020.

[13] F. Zhao, "Using quizizz to integrate fun multiplayer activity in the accounting classroom," Int. J. High. Educ., vol. 8, no. 1, pp. 37-43, 2019, doi: 10.5430/ijhe.v8n1p37.

[14] L. S. L. Purba, "Peningkatan Konsentrasi Belajar Mahasiswa Melalui Pemanfaatan Evaluasi
Pembelajaran Quizizz Pada Mata Kuliah Kimia Fisika I," J. Din. Pendidik., vol. 12, no. 1, p. 29, 2019, doi: 10.33541/jdp.v12i1.1028.

[15] I. Sinta, D. Rahayu, and P. Purnawarman, "The Use of Quizizz in Improving Students ' Grammar Understanding through SelfAssessment," vol. 254, no. Conaplin 2018, pp. 102-106, 2019.

[16] C. Nkhoma, M. Nkhoma, S. Thomas, and L. K. Tu, "Gamifying a Flipped First Year Accounting Classroom Using Kahoot!," Int. J. Inf. Syst. Eng., vol. 6, no. 2, pp. 93-115, 2018, doi: 10.24924/ijise/2018.11/v6.iss2/93.115.

[17] E. P. Widoyoko, "Teknik penyusunan instrumen penelitian," Yogyakarta: Pustaka Pelajar, 2016.

[18] A. Samala, B. Fajri, and F. Ranuharja, "DESAIN DAN IMPLEMENTASI MEDIA PEMBELAJARAN BERBASIS MOBILE LEARNING MENGGUNAKAN MOODLE MOBILE APP", tip, vol. 12, no. 2, pp. 13-20, Dec. 2019. 